\title{
Review \\ Nutritional Properties of Camelids and Equids Fresh and Fermented Milk
}

\author{
Paolo Polidori ${ }^{1, *(\mathbb{C})}$, Natalina Cammertoni ${ }^{2}$, Giuseppe Santini ${ }^{2}$, Yulia Klimanova ${ }^{2}{ }^{\mathbb{C}}$, Jing-Jing Zhang ${ }^{2}$ \\ and Silvia Vincenzetti ${ }^{2}$ (D) \\ 1 School of Pharmacy, University of Camerino, 62032 Camerino, Italy \\ 2 School of Biosciences and Veterinary Medicine, University of Camerino, 62024 Matelica, Italy; \\ natalina.cammertoni@unicam.it (N.C.); giuseppe.santini@unicam.it (G.S.); yulia.klimanova@unicam.it (Y.K.); \\ jingjing.zhang@studenti.unicam.it (J.-J.Z.); silvia.vincenzetti@unicam.it (S.V.) \\ * Correspondence: paolo.polidori@unicam.it; Tel.: +39-0737-403426
}

Citation: Polidori, P.; Cammertoni, N.; Santini, G.; Klimanova, Y.; Zhang, J.-J.; Vincenzetti, S. Nutritional Properties of Camelids and Equids Fresh and Fermented Milk. Dairy 2021, 2, 288-302. https://doi.org/ 10.3390/dairy2020024

Academic Editor: Antonio-Jose Trujillo

Received: 14 May 2021

Accepted: 31 May 2021

Published: 7 June 2021

Publisher's Note: MDPI stays neutral with regard to jurisdictional claims in published maps and institutional affiliations.

Copyright: (c) 2021 by the authors. Licensee MDPI, Basel, Switzerland. This article is an open access article distributed under the terms and conditions of the Creative Commons Attribution (CC BY) license (https:// creativecommons.org/licenses/by/ $4.0 /)$.

\begin{abstract}
Milk is considered a complete food because all of the nutrients important to fulfill a newborn's daily requirements are present, including vitamins and minerals, ensuring the correct growth rate. A large amount of global milk production is represented by cow, goat, and sheep milks; these species produce about $87 \%$ of the milk available all over the world. However, the milk obtained by minor dairy animal species is a basic food and an important family business in several parts of the world. Milk nutritional properties from a wide range of minor dairy animal species have not been totally determined. Hot temperatures and the lack of water and feed in some arid and semi-arid areas negatively affect dairy cows; in these countries, milk supply for local nomadic populations is provided by camels and dromedaries. The nutritional quality in the milk obtained from South American camelids has still not been completely investigated, the possibility of creating an economic resource for the people living in the Andean highlands must be evaluated. Both mare and donkey milks show a chemical composition very similar to human milk, and they represent a good replacer of cows' milk for infants nutrition, especially for children affected by cow milk proteins allergy. In this review, differences and similarities in the quality parameters of milk from minor dairy animals, such as camelids and equids, have been compared.
\end{abstract}

Keywords: camelids; equids; milk; functional foods

\section{Introduction}

Cows are considered the main dairy animal. The term "milk" is normally associated with cow milk in most people's minds, because of the great amount of bovine milk produced worldwide; in 2020 the reported data had risen to around 532 million metric tons [1]. Obviously, considering the financial reasons involved in the dairy industry, most of the studies investigating the milk quality parameters have been performed firstly on bovine's milk, and later on other ruminants' milk, such as ewe, goat and buffalo milk [2].

The milk and dairy products from minor mammalian species, such as camelids and equids, are not important considering the economic point of view, but these animals are crucial in the agricultural systems in several parts of the world, especially in many marginal and poor areas of North Africa, the Middle East, South America and Eastern Europe [3]. Most of the people living in these regions of the world belong to pastoral societies; their main activity consists of breeding livestock using natural pastures as forage [4]. These pastures are normally located in deserts, mountains and steppes, but it is impossible to cultivate or use these lands for agricultural activities; this kind of land represents about $25 \%$ of the world's surface [4]. 


\subsection{Camelids Milk}

Camelids are in the taxonomic order Artiodactyla (even toed ungulates), the suborder Tylopoda (pad-footed), and the family Camelidae. Camels can be considered important dairy animals for people living in arid and semi-arid areas of the world [5]. In the desert areas of the Middle East, North and East Africa, and Southwest Asia, the dromedary or Arabian camel (single-humped) is the most common camel species, while in Northwestern China and Mongolia, Southern Russia, Tajikistan and Kazakhstan, the Bactrian camel (two-humped) is the most diffused camel species [6]. The biggest amount of the world camel milk production (more than $87 \%$ ) is located in sub-Saharan Africa [7]. Somalia is the first country producer of camel milk (53\% of world global production), the second one is Ethiopia (12\%), and Mali (8\%) is the third one [1]. Camelids are herbivores with three stomachs, and their digestive physiology is very similar compared to other ruminants with four stomachs, so they have been defined "pseudo-ruminants" [8].

There are the following four species of South American camelids: vicuña, guanaco, llama, and alpaca; vicuña and guanaco are wild, and llamas and alpacas are domesticated species [9]. These animals provide meat and milk for the local populations living in the Andean highlands, but milk from the alpaca and/or llama is not regularly collected for human feeding.

\subsection{Equids Milk}

The domestic equid species (horse and donkey) belong to the taxonomic order Perissodactyla, the family Equidae, and the genus Equus [10]. Since ancient times, donkey milk has been used for infant nutrition, and its therapeutic properties were widely known [11]. Mare and donkey milk supply is very low compared to conventional dairy species, with a great variability in milk production determined in different trials, due to different animal feeding, animal genetic, farm management, etc. [12]. Detailed statistical data are not available about the total equid milk production all over the world, their contribution is estimated to be less than $0.1 \%$ [13].

Human and equine milk are similar in terms of carbohydrates (lactose and galactose), and protein and mineral contents, but they have a significantly different fat content, which is markedly higher in human breastmilk [14]. Equine milk has been used in many clinical trials involving children affected by food allergies [15]. In particular, donkey milk has been widely used in several diets of children affected by cows' milk protein allergy (CMPA), the most common food allergy in childhood during the first three years of life, showing a high palatability as a consequence of the high lactose content, together with a low allergenicity due to the presence of specific nitrogenous components [16]. Equine milk can be considered a good replacer of dairy cows' milk in the dietary treatment of children affected not only by immunoglobulin E-mediated CMPA, but also by food protein-induced enterocolitis, normally occurring during the first year of life [17].

It has been known for a long time that donkey's milk has been used as a body lotion by the queen Cleopatra in ancient Egypt, because this product was able to preserve the skin's beauty [18]. Later, during the Roman age, the Emperor Nero's wife, Poppea, used the same milk with the same aim. The use of donkey milk for beauty face treatments has been described by Ovid in a book named Medicamina Faciei Femineae, [19]. Actually, the cosmetic industry is still greatly interested in using equid milk to produce soaps and beauty creams. In the past, chemical products have been used to replace more expensive natural ingredients in cosmetic products, to reduce the production costs and increase, in this way, the market share. In the actual XXI century, consumers demand of cosmetic products is greatly orientated towards the use of healthy products, with particular care in the use of natural ingredients in the preparation of body lotions, face creams, etc. [20]. Consequently, the interest of the cosmetic industry has been recently redirected towards the use of equid milk in the preparation of beauty products, with the aim of promoting sustainable consumption. 
The aim of the present review is to compare the quality parameters of milk produced by domesticated minor species, namely, camelids and equids, in order to identify the best target of consumers for these niche foods. The milk from these species is produced in small yields, but it is important for fulfilling the nutrient requirements of human beings in specific regions of the world, contributing significantly to the nutritional status and to the well-being of these people.

\section{Camel Milk}

The camel population in the world accounts about $27,000,000$ heads, most of them located in Africa (about 23,000,000), while the remaining 4,000,000 are in Asia; more than 24,000,000 are one-humped dromedary camels (Camelus dromedarius), and 3,000,000 are two-humped (Camelus bactrianus) [21]. Camel milk world production was estimated to be about 2.85 million tons in 2019 , which represents $0.35 \%$ of the milk consumed in the world [22]; the total amount is increasing year by year [23].

Camel milk is an important food in the human diet in several parts of the word; it represents one of the main sources of proteins for a large part of nomadic populations living in Africa and in Asia, and it can basically be considered the only protein source in infant nutrition for the desert people [24].

Milk production from Indian camel such as Bikaneri, Jaisalmeri, and Kachchhi were reported, respectively, as $3.22 \pm 0.15,2.17 \pm 0.16$ and $3.94 \pm 0.13 \mathrm{~L} /$ day. The lactation length is around 14-16 months, the fresh milk represents daily food for the local population [25]. Camel milk has been used for treating infectious diseases such as tuberculosis in humans, and is also administered in Kazakhstan together with drugs in the chemotherapy treatments for cancers of the digestive tract [26].

Camel milk is characterized by an opaque white color, a faint sweetish odor with a sharp salty taste, and the $\mathrm{pH}$ value ranges from 6.2 to 6.5. The opaque white color is due to the presence of lipids finely homogenized in the milk [27]. The chemical composition determined in different studies is shown in Table 1.

Table 1. Milk chemical composition and energy in mammalian species (g/100 g).

\begin{tabular}{ccccc}
\hline & Energy (kJ) & Fat & Proteins & Lactose \\
\hline Dromedary camel & 277 & 3.1 & 3.5 & 4.4 \\
Bactrian camel & 372 & 5.3 & 3.9 & 4.5 \\
Cow & 300 & 3.7 & 3.3 & 4.7 \\
Sheep & 470 & 7.0 & 6.0 & 4.9 \\
Goat & 270 & 4.7 & 3.8 & 4.3 \\
Human & 269 & 3.0 & 1.5 & 6.8 \\
\hline
\end{tabular}

Source: [28].

The lactose, fat and protein content in dromedary milk is not so different compared to bovine milk, but the protein profile of camel and bovine milk is very different. Camel whey proteins, in fact, do not contain $\beta$-lactoglubulin, which represents more than $50 \%$ of cows' milk whey proteins, while $\alpha$-lactalbumin ( $\alpha$-la; 27\%), serum albumin (SA; 26\%) and immunoglobulins (18\%) are the most represented protein fractions in camel milk [29].

Camel milk shows antibacterial and antiviral activities due to the bioactive peptides that perform an important physiological activity, enhancing the immune system defense [30]. Camel milk, in fact, has been used from ancient times as a remedy for diarrhea caused by viruses (Rota virus); recently its use has been evaluated in several clinical trials as a possible therapy [31].

The camel's immune system, compared to the human one, is stronger; the small immunoglobulins are transferred from the camel milk directly into the human blood [32]. In camel milk immunoglobulins can be detected during the entire lactation, so drinking camel milk can enhance the immune system, representing a treatment for autoimmune diseases. In fact, the small camel's immunoglobulins pass into the milk, and for this reason they are able to be used for treating autoimmune diseases and are active against antigens [33]. 
Normally, conventional treatments for autoimmune diseases are based on immune suppression; using camel milk, the immune system is enhanced by the immunoglobulins because the immune integrity is revitalized [25].

Camel milk shows positive effects in the treatment of tuberculosis (TB), especially in patients suffering from multiple drug-resistant (MDR) tuberculosis [34]. The authors of this clinical trial detected protective proteins in the camel milk, showing a peculiar role for enhancing the mechanisms of immune defense. In particular, camel milk proteins have specific antibacterial properties, enabling them to destroy Mycobacterium tuberculosis.

The area in which the animals are bred influences significantly the total protein content of the dromedary's milk [35]. Considering the specific protein fractions, caseins represent around $80 \%$ of the total milk protein content, while the remaining $20 \%$ of the whey proteins contains several soluble proteins and bioactive peptides generated by camel milk proteases, specifically chymotrypsin A and cathepsin D [36]. Casein in the camel's milk has the following four fractions: $\alpha \mathrm{s} 1, \alpha \mathrm{s} 2, \beta$ and k-casein; $\beta$-casein and $\alpha$-casein represent 65 and $21 \%$ of the total casein, respectively, while k-casein is lower, representing $3.47 \%$ [37]. The $\beta$-casein is hydrolyzed in the gut; for this reason, camel's milk is more digestible and less allergic for people, providing beneficial effects for human health.

The main whey protein in camel's milk is represented by $\alpha$-lactalbumin, which is easily digestible, while the lack of $\beta$-lactoglobulin in this milk makes it less allergenic when administered in infant nutrition [38]. The following other whey proteins are present: lactoferrin content ranges from 0.02 to $2.1 \mathrm{~g} / \mathrm{L}$, lysozyme shows a concentration around $150 \mu \mathrm{g} / \mathrm{L}$, and finally immunoglobulins (IgG) are present too. These whey proteins are very important for creating the passive immunity in newborns; IgG is the main $(10 \mathrm{~g} / \mathrm{L})$ immunoglobulin detected in camel's milk [38].

Regular drinking of dromedary milk in the Middle East and in India is considered a strategy in the prevention and control of diabetes [39]. The ability of treating diabetes mellitus is in fact considered the main health-promoting property of dromedary milk, due to its hypoglycemic effect. For this reason, there is a large use of dromedary milk in diabetic patients, together with insulin therapy [40]. This anti-diabetic effect of dromedary milk is probably due to the lack of milk coagulation in the stomach, with a consequently higher resistance of milk insulin in the gastrointestinal tract [41]. The presence of some milk insulin-like molecules still unknown in camel milk has been suggested as being another possible cause of the anti-diabetic effects [42].

A treatment lasting $30-40$ days, during which dromedary milk was administered in patients suffering with autism spectrum disorders, showed positive effects on cognitive and communication skills [43]. Neurological diseases, such as autism spectrum disorders, are normally associated with oxidative stress and low levels of antioxidant enzymes; considering the antioxidant properties of dromedary milk, a therapy based on the use of this milk has been suggested [44].

Camel milk has also been used in children showing severe cows' milk allergies; after camel milk administration, the children showed a rapid improvement [43]. Protein fractions are considered the crucial molecules for preventing and treating food allergies. Specifically, in camel milk the following protein profile characteristics have been determined:

(a) $\beta$-lactoglobulin has not been detected in camel's milk;

(b) Different $\beta$-casein has been detected in camel's milk;

(c) Immunoglobulins similar to those detected in human milk have been found in camel's milk too; the use of camel's milk may reduce children's allergic reactions and reinforce their future response to foods [45].

A recent review investigated in detail the physicochemical composition and the functional properties of camel milk to understand the effects on child nutrition [46]. The high contents in camel milk of protective proteins, minerals, and vitamin C, together with a balanced ratio of saturated and unsaturated fatty acids, fulfill the nutrients requirements for a regular child's growth performance. Several clinical trials investigated the therapeutic effects of camel milk, evaluating its antimicrobial, antioxidant, anticancer, anti-hepatic, and 
anti-inflammatory activities [47]. The basic statement from this review attributed valuable nutritional properties to camel milk, mainly related to the content of a high proportion of antibacterial substances.

The total mineral content of camel's milk ranges between 0.60 and $0.90 \%$, similarly to cow's milk; the salty flavor of this milk can be due to the high chloride content [38]. Camel's milk is rich in water-soluble vitamins, especially vitamin $B_{1}$, vitamin $B_{2}$ and vitamin $C$, which is five times higher compared to cow's milk, being very important in human diet in arid areas where it is hard to provide green foods [48].

The effects of pasteurization on the fouling behavior of raw camel milk have been evaluated; this thermal treatment resulted in reduced fouling [49]. The protein profiles are very different among dairy cows' and camel milk, as follows: $\beta$-lactoglobulin, the main factor in cows' milk fouling, is not present in camel milk, while caseins, $\alpha$-lactalbumin, serum albumin and peptidoglycan are responsible for camel milk fouling. Camel milk showed a lower fouling resistance compared to cows' milk, forming more porous deposits [49]. The effects of camel milk thermal treatments using high temperatures must be evaluated in further experiments, in order to determine camel milk therapeutic characteristics in raw, pasteurized and sterilized milk.

\section{South American Camelids Milk}

In South America, camelids include two wild species, which are the vicuna (Vicugna vicugna) and the guanaco (Lama guanacoe), and two domesticated species, which are the llama (Lama glama) and the alpaca (Lama pacos) [50]. The domestication of the llama and alpaca took place around 6000-7000 years ago in the Andean highlands, where both alpacas and llamas were raised for fiber production. Actually, llamas in South America are estimated to be about 4 million heads, mainly in Peru and Bolivia, but recently they have also been imported in Europe, North America, and Australia, always for fiber production [51]. The alpaca is smaller than the llama; recently also alpacas have been exported to other continents, such as North America, Australia, and Europe, where they are bred for both wool and meat production [52]. The actual Andean alpaca population is estimated to be close to 3 million heads [53].

Milk production in llamas shows significant variations among different animals, ranging from 16 to $413 \mathrm{~mL} /$ day, with an average of $62 \mathrm{~mL} /$ day per animal [54]. Alpaca milk shows higher protein and ash contents with respect to other camelids milk, while llama milk has a very high lactose content; both llama and alpaca milk showed high nutritional quality, and should be considered an alternative food for humans in the semi-arid region of South America. [55]. However, a recent study, in which the milk obtained from llamas and alpacas reared in the same lands was compared, found that the physicochemical composition of milk shows only a few statistical differences between llamas and alpacas [56].

The milk chemical composition in South American camelids is shown in Table 2.

Table 2. Milk chemical composition in South American camelids (g/100 g).

\begin{tabular}{cccc}
\hline & Alpaca & Llama & Vicugna \\
\hline Fat & 3.8 & 4.7 & 4.58 \\
Lactose & 6.9 & 5.93 & 7.43 \\
Proteins & 4.4 & 4.23 & 3.7 \\
Ash & 1.7 & 0.74 & n.d. \\
Dry Matter & 16.8 & 15.6 & n.d. \\
\hline
\end{tabular}

Source [51]; n.d.: not detected.

$\beta$-lactoglobulin is one of the major milk allergens causing CMPA in children [57]. Therefore, milk from species with a low $\beta$-lactoglobulin content or lower $\beta$-lactoglobulinto- $\alpha$-lactalbumin ratios are very interesting for human nutrition, especially in children affected by CMPA. Camel milk and llama milk do not contain $\beta$-lactoglobulin, such as human milk, but scarce data about the complete protein profile of these camelids milk are available [58]. 
Alpaca milk showed, both at 30 and 60 days of lactation, a higher content of CLA (conjugated linoleic acid, C18:2 cis-9, trans-11), which was, respectively, 1.83 and 1.67 ( $\mathrm{g} / 100 \mathrm{~g}$ total fatty acids) compared to llama milk $(0.70 \mathrm{~g} / 100 \mathrm{~g}$ total fatty acids) [52]. The CLA determined in both ruminant meat and milk originates from the incomplete biohydrogenation of linoleic acid in the rumen. Potential health benefits have been associated with CLA dietary consumption; for this reason, strategies for improving CLA content in ruminant meat and milk, including pseudo-ruminants such as camelids, has become an important objective in food research [59].

The essential fatty acids $n 6 / \mathrm{n} 3$ ratio in alpaca milk was 1.28 and 1.47 after 30 and 60 days of lactation, respectively; these values were closer to the one determined in cow's milk (1.97), compared to higher values reported in goat (3.73) and ewe milk (2.11) [52]. However, the chemical composition in alpaca milk during lactation did not show significant differences, confirming the results previously obtained in llama milk too [60].

\section{Equine Milk}

The nutritional and therapeutic characteristics of equids' milk are well known from ancient times [61]. Studies on equine milk's chemical composition have been recently performed in order to evaluate the effects on human nutrition, especially for special consumers categories, such as children with CMPA or the elderly [62]. Children affected by CMPA can safely consume equine milk because of the high similarity with human milk chemical composition [63]. However, although milks produced by species in the same taxonomic order tend to be fairly similar, donkey milk is characterized by a lower protein and fat content compared to mare's milk, while the lactose content is higher in donkey milk (Table 3). Mare's milk is considered a common beverage for about 30 million people in the world [64].

Table 3. Chemical composition of mare, donkey and human milk (g/100 g).

\begin{tabular}{ccccc}
\hline & Fat & Proteins & Lactose & Ash \\
\hline Mare & $0.5-2.00$ & $1.5-2.8$ & $5.8-7.0$ & $0.3-0.5$ \\
Donkey & $0.3-1.8$ & $1.3-2.0$ & $6.4-7.9$ & $0.3-0.5$ \\
Human & 3.4 & 1.3 & 6.9 & 0.2 \\
\hline
\end{tabular}

Source: [65].

Compared with dairy cows and other ruminant milks, in horse and donkey milk a lower casein-to-whey-protein ratio has been registered (Table 4), similar to the values reported in human milk [66]. For this reason, equids milks can be considered an attractive potential natural ingredient for infant formulas [67]. In fact, a lower casein-to-whey-protein ratio, due to the higher proportion of whey proteins, is responsible for milk proteins faster digestion in infant formulas compared to milks characterized by a casein-dominant protein composition [68]. Human milk has the lowest casein-to-whey-protein ratio, a high $\beta$-casein-to- $\alpha$ s-casein ratio and does not show $\beta$-lactoglobulin (Table 4). For this reason, milk from other mammalian species showing similar chemical and nutritional properties is very interesting for human nutrition and for the dairy industry too, as confirmed by the recent development of new dairy products targeted not only at children, but also at adult consumers [69]. 
Table 4. Protein profile (g/L) of milk from different mammalian species.

\begin{tabular}{ccccccc}
\hline Protein Fraction & Human & Cow & Sheep & Camel & Donkey & Mare \\
\hline Total caseins & $2.4-4.2$ & $24-28$ & $41-52$ & $22-26$ & $6.4-10.3$ & $9.4-13.6$ \\
Total whey proteins & $6.2-8.3$ & $5.5-7.0$ & $10.2-16.1$ & $5.0-8.1$ & $4.3-8.0$ & $7.4-9.1$ \\
Caseins / whey proteins ratio & $29.7-33.6$ & 82.2 & 76.2 & $73.3-76.2$ & 56.4 & 52.5 \\
$\alpha_{\mathrm{s} 1}$-casein & 0.77 & $8-10.7$ & $2.4-22.1$ & $4.0-5.7$ & Traces & 2.4 \\
$\alpha_{\mathrm{s} 2 \text {-casein }}$ & n.d. & $2.8-3.4$ & 6.0 & $2.1-2.5$ & Traces & 0.2 \\
$\beta$-casein & 3.87 & $8.6-9.3$ & $15.6-39.6$ & $14.4-16$ & Traces & 10.6 \\
k-casein & 0.14 & $2.3-3.3$ & $3.2-12.2$ & $0.8-0.9$ & Traces & 0.24 \\
$\alpha$-lactoalbumin & $1.9-3.4$ & $1.2-1.3$ & $1-1.9$ & $0.5-3.5$ & 1.9 & 2.37 \\
$\beta$-lactoglobulin & n.d. & $3.2-3.3$ & $6.5-13.5$ & n.d. & 3.3 & 2.55 \\
\hline
\end{tabular}

Source: [66]; n.d.: not detected.

In equids milk, the fat content is significantly lower compared to human milk (Table 3), with a consequently lower energy intake. Equids milk fat is characterized by a high level of polyunsaturated fatty acids (PUFA) and a low level of saturated fatty acids (FA) [70]. Among PUFA, equids milk shows essential fatty acids from both the omega 3 series (alpha-linolenic acid, ALA) and omega 6 series (linoleic acid, LA), which are precursors of docosahexaenoic acid (DHA) and arachidonic acid (AA), respectively. The high levels of these FA are due to the fact that equids are monogastric animals, therefore unsaturated fatty acids are not hydrogenated before absorption, differently to ruminants, where they are saturated during the rumen's fermentations [71]. The main differences in the fatty acid profile among mare and donkey milk can be summarized in the following two items: trans-FA and conjugated linoleic (CLA) have never been determined in donkey's milk, while small amounts of both trans-FA and CLA can be detected in mare's milk [58].

Compared to mammalians milk, several differences can be detected in plant-based beverages (Table 5). Soymilk protein content is the only one similar to cows' milk, with values in the range between $2.9-3.7 \%$; in all of the other beverages, lower protein contents have been determined. Moreover, vegetable proteins are normally characterized by a lower biological value compared to proteins in animal source foods because of the lack of essential amino acids, particularly lysine in cereals and methionine in legumes [72]. The nutritional quality of these beverages cannot be considered sufficient to cover the nutrients recommended daily intakes, particularly when administered as mammalian milk replacers for feeding children, representing a risk for a regular growth rate [73].

Table 5. Chemical composition comparison among mammalian's milk and plant-based beverages.

\begin{tabular}{ccccc}
\hline Food & $\begin{array}{c}\text { Fat } \\
(\mathbf{g} / \mathbf{1 0 0} \mathbf{g})\end{array}$ & $\begin{array}{c}\text { Proteins } \\
(\mathbf{g} / \mathbf{1 0 0} \mathbf{g})\end{array}$ & $\begin{array}{c}\text { Carbohydrates } \\
(\mathbf{g} / \mathbf{1 0 0} \mathbf{g})\end{array}$ & Energy (kcal) \\
\hline Cow [46] & 3.6 & 3.2 & 4.7 & 62 \\
Dromedary [46] & 3.1 & 3.5 & 4.4 & 66.1 \\
Llama [46] & 4.2 & 4.1 & 6.3 & 87.2 \\
Donkey [46] & 0.7 & 1.6 & 6.6 & 41.8 \\
Human [46] & 3.5 & 1.2 & 6.4 & 64.2 \\
Soy-based [58] & 1.9 & 2.9 & 0.8 & 32 \\
Almond [58] & 3.3 & 1.3 & 5.5 & 56 \\
Rice-based [58] & 0.97 & 0.28 & 9.17 & 47 \\
\hline
\end{tabular}

Plant-based beverages can cause nutritional deficit in babies; they generally show a low saturated FA content, and contain added sugars and sweeteners, with a substantial difference in the carbohydrates intake due to the absence of lactose and galactose in plantbased drinks [73]. Vegetable beverages normally need to be fortified because of the low proteins, fat-soluble vitamins and mineral content, especially calcium [74]. Considering the significant differences in the nutritional properties of milk and vegetable beverages, mammalians milk should not be replaced with these drinks in younger children's diets, after 
evaluating in the cases of CMPA the best alternative to cows' milk, carefully considering the minor dairy animals, including camelids and equids milk.

\section{Fermented Milks}

Yoghurt is the most common acidified fermented dairy product; it is prepared using cows' milk in which the symbiotic microorganisms Streptococcus thermophilus and Lactobacillus delbrueckii subsp. bulgaricus have been added [75]. Yoghurt consumption allows people with partial lactose intolerance to achieve a nutritional benefit from this food [76], and it can help to stabilize the gut microflora [77].

The chemical composition of donkey's milk does not permit cheese production, it is very hard to obtain a firm curd after rennet addition in donkey milk [78]. If donkey's milk $\mathrm{pH}$ values decrease under five, a weak coagulum is formed; so, the possibility of using donkey milk for fermented beverage production has been evaluated, following the example of the well-known fermented mare's milk production, the traditional and popular "koumiss" [79].

The first method developed about 10,000 years ago, specifically in the Middle East to preserve and store milk for longer times, has been use of fermentation. Fermented milks are still very popular, particularly in areas where the use of technical devices for thermal treatments, such as refrigeration, pasteurization, sterilization, etc., is not regularly diffused [80]. Fermented milks can be classified into the following three groups, based on the different fermentation applied [81]:

- Beverages obtained by lactic fermentations;

- Beverages obtained by yeast-lactic fermentations;

- Beverages obtained using mold-lactic fermentations (Geotrichum candidum).

Yeast-lactic fermentation is applied for koumiss and kefir production. Yeasts develop an alcoholic fermentation, together with a lactic acid fermentation developed by lactic bacteria. Fermented milk shows many important advantages, some are as follows: it represents an easy method to preserve milk; and fermentation improves milk's digestibility and provides a different functional food for human consumption. The first studies investigating on the health benefits of fermented milks declared that people with high per head consumption of fermented milks lived longer [82]. The suggested reason given by the author was the colonization of the human gastrointestinal tract, performed by the lactic acid bacteria present in the fermented beverage, decreasing consequently the 'putrefaction' caused by the pathogenic bacteria [83]. For the first time it was suggested that a probiotic effect was caused by the lactic bacteria, a slowing down of the aging process was reported. Later, several other studies have been performed to evaluate the main effects of probiotics. The results obtained in most of the trials showed an improvement in the digesta transit time in the human intestine, with a significant enhancement of the bowel function, a reduction in the glycemic index, and in some clinical trials an anticarcinogenic effect has been reported too [84].

\subsection{Koumiss}

Koumiss (also named Kumys) is a fermented mare's milk very popular in Russia, Mongolia and Kazakhstan, often used also as a medicine for the treatment of several illnesses, but unfortunately it is impossible to establish the real therapeutical properties because of the significant differences in bacteria content detected in koumiss produced in different areas [85]. Koumiss is considered the national drink in Mongolia, where it is also named Airag; the local population shows a koumiss consumption of about $50 \mathrm{~L} /$ head/year [61]. Koumiss traditionally produced is still popular in the internal regions of Mongolia, but recently new production methods have been developed due to the increased demand also from other countries. The traditional koumiss preparation was based on the inoculation of a mixture of bacteria and yeasts in fresh raw milk, then a part of the previous day's product was added. The time necessary for fermentation ranged from 3 to $8 \mathrm{~h}$; the milk was held in 
a leather container named the 'turdusk' (also named 'saba' or 'burduk'), which was made using smoked horse skin taken from the leg [86].

The average chemical composition in koumiss is as follows:

- Moisture content about $90 \%$;

- Total proteins content is in the range $2-2.5 \%$, with whey protein content $(0.9 \%)$ very close to the casein content (1.2\%);

- Lactose content is in the range $4.5-5.5 \%$;

- Fat content is about $1-1.3 \%$;

- Ash is $0.4-0.7 \%$.

Finally, the following products of the milk fermentation are also present in koumiss: lactic acid (1.8\%), ethanol $(0.6-2.5 \%)$ and $\mathrm{CO}_{2}(0.5-0.9 \%)$; the energy value ranges from 37 to $40 \mathrm{kcal} / 100 \mathrm{~mL}$. Koumiss is effervescent due to the presence of gas produced during fermentation, mainly $\mathrm{CO}_{2}$. During milk fermentation, several new bioactive peptides and antibacterial molecules are produced; for this reason, koumiss shows a better efficacy in disease treatments compared to raw mare milk consumption [64]. To obtain a good koumiss, lactic and alcoholic fermentations must proceed together, producing all of the fermentation products in specific proportions. The final aroma and koumiss taste are in fact strongly influenced by lactic acid, ethanol, $\mathrm{CO}_{2}$, volatile fatty acids, and other compounds; at the end of the process, around 10\% of the mare's milk proteins are hydrolyzed. Normally, the following three categories of koumiss are classified according to the different levels of lactic acid and ethanol [61]:

- Mild-the acidity ranges between 0.6 and $0.8 \%$, and the alcohol content is between 0.7 and $1.0 \%$;

- Medium - the acidity ranges between 0.8 and $1.0 \%$, and the alcohol content is about $1.1-1.8 \%$;

- Strong-the acidity is around $1.0-1.2 \%$, and the alcohol is $1.8-2.5 \%$.

\subsection{Donkey Milk Fermented Beverages}

Donkey's milk shows a chemical composition similar to mare's milk, but there is a significant difference in the lysozyme content, a bioactive peptide detected in a higher proportion in donkey's milk [87]. Lysozyme is characterized by strong antibacterial properties, therefore the selection of bacteria for preparing fermented donkey's milk must be very accurate. Lactic acid bacteria (LAB), normally present in donkey's milk, have been isolated for the first time in 2014 [88]. The aim of that study was to characterize starter cultures useful to produce donkey's milk fermented beverages. Only a few species of LAB were detected in donkey's milk, and the authors did not detect any LAB belonging to the most common starter cultures normally used in dairy technology. The diversity of LAB detected in donkey's milk was justified considering the resistance to coccus-shaped bacteria caused by the high lysozyme content, while lactobacilli are less affected by lysozyme.

In 2002, the use of selected Lactobacillus rhamnosus strains was investigated for the first time in donkey's milk to create a probiotic beverage [79]. The same group of authors created another fermented beverage inoculating, in donkey's milk, only LAB with probiotic activity [85]. A panel test was performed to evaluate the sensorial properties of the fermented milk in relation to the bacteria used in the trial. The fermented beverage was produced using pasteurized donkey's milk $\left(63^{\circ} \mathrm{C}\right.$ for $\left.30 \mathrm{~min}\right)$. The following different amounts of pre-culture strains were inoculated: $3 \mathrm{~mL}$ of Lactobacillus rhamnosus AT194, $4 \mathrm{~mL}$ of Lactobacillus rhamnosus CLT 2/2, and $4 \mathrm{~mL}$ of L. casei. The total amount of the strains inoculated at the beginning of the study $(\mathrm{t}=0)$ was about $106-107$ cells $/ \mathrm{mL}(3 \%$ each culture); and the temperature during the inoculation was $37^{\circ} \mathrm{C}$. Every $12 \mathrm{~h}$ after inoculation, the $\mathrm{pH}$ value was determined; when the $\mathrm{pH}$ reached values between 4.5 and $4.6(t=2)$, microbiological analyses were performed after 7,15 and 30 days to determine the product's shelf life. The fermentation process was fast and effective, according to the changes reported in the titratable acidity. Two days after inoculation, the lactic bacteria total load was about $108 \mathrm{cfu} / \mathrm{mL}$ and the same amount of LAB was obtained 30 days 
after inoculation $(108 \mathrm{cfu} / \mathrm{mL})$. This result clearly showed that the strains used in this trial remained viable during the storage of the fermented donkey's milk. The three different strains used in his study produced fermented milk with different flavors, as follows:

- $\quad$ L. casei strain produced a fermented milk with a tasty aroma;

- The beverage produced with strain AT194 showed an unpleasant taste of cooked vegetables and sour milk;

- The use of strain CLT 2/2 produced a fermented beverage with the taste of fresh milk.

This study showed that donkey's milk can be used for producing a fermented beverage characterized by different nutritional qualities, which can be considered a functional food due to the high content of probiotic bacteria.

A fermented beverage was produced using donkey milk as a raw material, inoculating only traditional culture starters, specifically Lactobacillus bulgaricus and Streptococcus thermophilus [75]. Fermented beverages were prepared using only donkey's milk for the first three samples, and later six different mixed milk combinations (Table 6). The starter culture was added in the amount shown in Table 6.

Table 6. Different milks and starter culture percentage used for fermented beverage production.

\begin{tabular}{cc}
\hline Milk & \% Starter Culture \\
\hline 100\% donkey & 3.0 \\
100\% donkey & 4.5 \\
100\% donkey & 6.0 \\
$90 \%$ donkey-10\% ovine & 3.0 \\
80\% donkey-20\% ovine & 3.0 \\
$70 \%$ donkey-30\% ovine & 3.0 \\
$90 \%$ donkey-10\% bovine & 3.0 \\
80\% donkey-20\% bovine & 3.0 \\
$70 \%$ donkey-30\% bovine & 3.0 \\
\hline
\end{tabular}

Source: [75].

When only donkey milk was inoculated with doses of 3 and $4.5 \%$ of starter culture, coagulation was not achieved. When $6 \%$ starter culture was inoculated on pure donkey's milk, a partial coagulation was achieved. Then ovine milk was mixed with donkey milk in the following three different concentrations: $10 \%, 20 \%$ and $30 \%$. Coagulation was achieved only when $30 \%$ ovine milk was added to the donkey's milk, inoculating a 3\% starter culture. The same result was achieved inoculating 3\% of starter culture to a mixture of $30 \%$ of bovine milk and 70\% of donkey's milk.

The sensorial analysis performed in this study showed that best texture and the most tolerated acidity have been attributed to the fermented milk prepared using a mixture of $70 \%$ donkey- $30 \%$ ovine milk, while the fermented beverage prepared using a mixture of $70 \%$ donkey- $30 \%$ bovine milk was described as the one with the better color and taste.

In conclusion, the results obtained in this study showed that it is possible to produce a fermented beverage using donkey milk as the main ingredient and then mixing it with other milks in smaller percentages. Mixing milks from different species can lead to an improvement in the final sensorial characteristics of this new beverage, increasing consumer's acceptance.

\subsection{Donkey Milk Kefir}

Kefir is an ancient fermented dairy food produced using kefir grains or starter cultures still widely consumed in former Soviet countries for treating allergies, gastrointestinal disorders, hypertension, and cardiovascular diseases [89]. Both lactic and alcoholic fermentations in kefir are responsible for the presence of a complex mixture of acetic and lactic acid bacteria, yeasts, and fungi in this beverage. Kefir is also rich in molecules showing antiproliferative activities, such as bioactive peptides, polysaccharides, sphingolipids and lysozyme; for these reasons kefir's nutritional properties have been frequently investigated by several scientists [81]. 
A study has been performed to evaluate the possible effects of donkey's milk kefir intake on apoptosis, cell proliferation and oxidative stress in a mouse model of solid Ehrlich ascites carcinoma (EAC) [90]. The experiment lasted 10 days and the animals were killed on the following day 11. A caliper was used to measure the diameters of the tumors after they have been removed from the animal's bodies; the tumor's volume was reduced by $25 \%$ in the mice belonging to the donkey's milk kefir group compared to the control group. This study confirmed the specific antiproliferative effects toward breast cancer cells shown by extracts during the early stage of donkey's kefir fermentation, and also by extracts from the final fermented kefir [91]. The tumor's volume reduction after donkey's milk kefir intake, obtained by inducing apoptosis and suppressing proliferation, took the authors to the conclusions that donkey's milk kefir in human diet can be useful for reducing breast cancer risk.

\subsection{Fermented Camel Milk}

The production of fermented camel and dromedary milk has not been yet deeply investigated. The antidiabetic effects of fermented camel milk after inoculation of two probiotic bacteria, Lactococcus lactis KX881782 and L. acidophilus DSM9126, have been evaluated [92]. Fermented camel milk significantly enhanced the inhibition of $\alpha$-amylase, while fermented dairy cows' milk did not significantly affect the $\alpha$-amylase inhibition [93].

The effects of camel milk fermented with lactobacilli compared to the same fermented dairy cows' milk showed that fermented camel milk has a higher ability to perform antihypertensive activities [94]. Camel milk fermented using probiotic strains of L. helveticus LMG11445 and St. thermophilus ATCC 19,258 showed blood pressure lowering effects on hypertensive rats [95].

These preliminary results performed in vitro must be supported by further clinical studies investigating on the clinical effects caused by the consumption of camel milk fermented by probiotic bacteria.

\section{Conclusions}

Milk chemical composition is different across species, reflecting the specific nutrient requirements of newborns. The best food for children is obviously represented by human milk, in the first 6 months of life it is generally recommended to exclusively breastfeed. When it is not possible to breastfeed, infant formulas based on dairy cows' milk are considered the most common replacer for human milk, but bovine milk is not available everywhere; dairy cows are widely diffused in temperate areas, but these animals do not fit in tropical or equatorial regions because of the hard climate conditions.

Camel milk is mainly used in areas where it is hard breeding other livestock; this food represents an important source of nutrients for nomadic populations living in the arid lands of the world, and shows benefits for human health due to some specific proteins that are able to enhance the human immune system. The results obtained in several clinical trials showed the benefits of camel milk, especially for children in the treatment of autism, and its improvements in general well-being.

There are not accurate data about human consumption of llama or alpaca milk. In llama milk, the low fat and salt content, together with the high $\mathrm{Ca}$ and P levels, also considering the lack of $\beta-1$ actoglobulin, may make this milk a healthy alternative to cows ${ }^{\prime}$ milk for human consumption. Alpaca milk's chemical composition showed a high protein content, a low percentage of short chain FA, and a higher content of both unsaturated FA and CLA compared to other ruminants' milk.

The data shown in the present review confirmed the potential useful application of equine milk in infant feeding, for both mare and donkey milk, mainly due to the great similarity in the protein content compared to human milk. Among domesticated equids, mare's milk is mainly consumed in central Asia and Eastern Europe, while donkey milk is popular in the Mediterranean basin, and in the arid and semi-arid areas of Africa and Asia. 
The nutritional value of milk from minor dairy animals can be further evaluated, even if the milk of these mammals is produced for human consumption only in certain parts of the world, but it is important for the nutritional status and for people's well-being in specific regions where dairy cow milk production is not possible.

Author Contributions: Conceptualization, P.P. and S.V.; data curation, N.C., G.S., Y.K. and J.-J.Z.; writing-original draft preparation, G.S., Y.K. and J.-J.Z.; writing-review and editing, P.P. and S.V.; visualization, J.-J.Z., G.S., Y.K. and N.C.; supervision, S.V. and P.P.; All authors have read and agreed to the published version of the manuscript.

Funding: This research received no external funding.

Informed Consent Statement: Not applicable.

Data Availability Statement: Not applicable.

Conflicts of Interest: The authors declare no conflict of interest.

\section{References}

1. STATISTA Database. Available online: https://www.statista.com/statistics/263952/production-of-milk-worldwide/ (accessed on 28 May 2021).

2. Faccia, M.; D'Alessandro, A.G.; Summer, A.; Hailu, Y. Milk Products from Minor Dairy Species: A Review. Animals 2020, 10, 1260. [CrossRef]

3. Miraglia, N.; Salimei, E.; Fantuz, F. Equine milk production and valorization of marginal areas-A review. Animals 2020, 10, 353. [CrossRef] [PubMed]

4. Degen, A.A. Sheep and goat milk in pastoral societies. Small Rumin. Res. 2007, 68, 7-19. [CrossRef]

5. Faraz, A.; Waheed, A.; Tauqir, N.A.; Mirza, R.H.; Ishaq, H.M.; Nabeel, M.S. Characteristics and Composition of Camel (Camelus dromedarius) Milk: The White Gold of Desert. Adv. Anim. Vet. Sci. 2020, 8, 766-770. [CrossRef]

6. Alhadrami, G.A. Camel. In Encyclopedia of Dairy Sciences; Roginski, H., Fuquay, J.W., Fox, P.F., Eds.; Academic Press: London, UK, 2003; pp. 616-622.

7. Faraz, A.; Waheed, A.; Mirza, R.H.; Nabeel, M.S.; Ishaq, H.M. Milk yield and composition of Barela dromedary camel in Thal Desert Punjab, Pakistan. Pak. J. Zool. 2020, 52, 1221-1224. [CrossRef]

8. Schoos, V.; Medina, M.; Saad, S.; Van Nieuwenhove, C.P. Chemical and microbiological characteristics of llamas' (Lama glama) milk from Argentina. Milchwissenschaft 2008, 63, 398-401.

9. Burton, S.; Robinson, T.F.; Roeder, G.L.; Johnson, N.P.; Latorre, E.V.; Reyes, S.B.; Schaajle, B. Body condition and blood metabolite characterization of alpaca (Lama pacos) three months prepartum and offspring three months postpartum. Small Rumin. Res. 2003, 48, 69-76. [CrossRef]

10. Salimei, E.; Fantuz, F. Equid milk for human consumption. Int. Dairy J. 2012, 24, 130-142. [CrossRef]

11. Iacono, G.; Carroccio, A.; Cavataio, F.; Montalto, G.; Soresi, M.; Balsamo, V. Use of ass's milk in multiple food allergy. J. Pediatr. Gastroent. Nutr. 1992, 14, 177-181. [CrossRef]

12. Polidori, P.; Vincenzetti, S. Farm Management and Feeding Strategies for Donkey Milk Production. In Agricultural Research Updates; Gorawala, P., Mandhatri, S., Eds.; Nova Science Publishers Inc.: New York, NY, USA, 2017; Volume 14, pp. 93-111.

13. Camillo, F.; Rota, A.; Biagini, L.; Tesi, M.; Fanelli, D.; Panzani, D. The current situation and trend of donkey industry in Europe. J. Equine Vet. Sci. 2018, 65, 44-49. [CrossRef]

14. Massouras, T.; Triantaphyllopoulos, K.A.; Theodossiou, I. Chemical composition, protein fraction and fatty acid profile of donkey milk during lactation. Int. Dairy J. 2017, 75, 83-90. [CrossRef]

15. Polidori, P.; Ariani, A.; Vincenzetti, S. Use of Donkey Milk in Cases of Cow's Milk Protein Allergies. Int. J. Child Health Nutr. 2015, 4, 174-179. [CrossRef]

16. Sarti, L.; Martini, M.; Brajon, G.; Barni, S.; Salari, F.; Altomonte, I.; Ragona, G.; Mori, F.; Pucci, N.; Muscas, G.; et al. Donkey's milk in the management of children with cow's milk protein allergy: Nutritional and hygienic aspects. Ital. J. Pediatr. 2019, 45, 102-110. [CrossRef]

17. Restani, P.; Ballabio, C.; Di Lorenzo, C.; Tripodi, S.; Fiocchi, A. Molecular aspects of milk allergens and their role in clinical events. Anal. Bioanal. Chem. 2009, 395, 47-56. [CrossRef]

18. Cunsolo, V.; Saletti, R.; Muccilli, V.; Gallina, S.; Di Francesco, A.; Foti, S. Proteins and bioactive peptides from donkey milk: The molecular basis for its reduced allergenic properties. Food Res. Int. 2017, 99, 41-57. [CrossRef] [PubMed]

19. Cosentino, C.; Freschi, P.; Paolino, R.; Valentini, V. Market sustainability analysis of donkey milk cosmetics. Emir. J. Food Agric. 2013, 25, 635-640. [CrossRef]

20. Cunsolo, V.; Muccilli, V.; Fasoli, E.; Saletti, R.; Righetti, P.G.; Foti, S. Poppea's bath liquor: The secret proteome of she-donkey's milk. J. Proteom. 2011, 74, 2083-2099. [CrossRef]

21. Idrees, E.M.; Ishag, I.A.; Eisa, M.O. Factors Affecting Chemical Properties of Camel Milk. Sci. Agric. 2016, 16, 49-53. 
22. Faye, B. The role of camelid in food security in the arid zone: Meat and milk production potential. In Book of Abstracts, Proceedings of the 70th Annual Meeting of the European Federation of Animal Science, Ghent, Belgium, 26-30 August 2019; Elsevier Press: Amsterdam, The Netherlands, 2019; p. 587.

23. Khalesi, M.; Salami, M.; Moslehishad, M.; Winterburn, J.; Moosavi-Movahedi, A.A. Biomolecular content of camel milk: A traditional superfood towards future healthcare industry. Trends Food Sci. Technol. 2017, 62, 49-58. [CrossRef]

24. Al Haj, O.A.; Al Kanhal, H.A. Compositional, technological and nutritional aspects of dromedary camel milk. Int. Dairy J. 2010, 20, 811-821. [CrossRef]

25. Yadav, A.K.; Kumar, R.; Priyadarshini, L.; Singh, J. Composition and medicinal properties of camel milk: A Review. Asian J. Dairy Food Res. 2015, 34, 83-91. [CrossRef]

26. Konuspayeva, G.; Faye, B.; Loiseau, G. Variability of vitamin C content in camel milk from Kazakhstan. J. Camelid Sci. 2011, 4, 63-69.

27. Mal, G.; Suchitra Sena, D.; Jain, V.K.; Sahani, M.S. Therapeutic value of camel milk as a nutritional supplement for multiple drug resistant (MDR) tuberculosis patients. Israel J. Vet. Med. 2006, 61, 88-94.

28. Mal, G.; Suchitra Sena, D.; Sahani, M.S. Changes in chemical and macro-minerals content of dromedary milk during lactation. J. Camel Pract. Res. 2007, 14, 195-197.

29. Kamoun, M.; Jemmali, B. Milk yield and characteristics of Tunisian camel. J. Anim. Sci. 2012, 1, 12-13.

30. El-Agamy, S.I.; Ruppanner, R.; Ismail, A.; Champagne, C.P.; Assaf, R.J. Antibacterial and Antiviral activity of camel milk protective proteins. J. Dairy Res. 1992, 59, 169-175. [CrossRef]

31. Zibaee, S.; Hosseini, S.M.; Yousefi, M.; Taghipour, A.; Kiani, M.A.; Reza Noras, M. Nutritional and Therapeutic Characteristics of Camel Milk in Children: A Systematic Review. Electr. Phys. 2015, 7, 1523-1528. [CrossRef]

32. Hoelzer, W.; Muyldermans, S.; Wernery, U. A note on camel IgG antibodies. J. Camel Pract. Res. 1998, 5, $187-188$.

33. Hamers, R. Immunology of camels and llamas. In Handbook of Veterinary Immunology; Pastoret, P.P., Griebel, P., Gaevarts, A., Eds.; Academic Press: London, UK, 1998; pp. 421-437.

34. Mal, G.; Suchitra Sena, D.; Jain, V.K.; Sahani, M.S. Therapeutic utility of camel milk as nutritional supplement in chronic pulmonary tuberculosis. Livest. Int. 2001, 7, 4-8.

35. Mati, A.; Senoussi-Ghezali, C.; Zennia, S.S.A.; Almi-Sebbane, D.; El-Hatmi, H.; Girardet, J.M. Dromedary camel milk proteins, a source of peptides having biological activities e A review. Int. Dairy J. 2017, 73, 25-37. [CrossRef]

36. Alhaider, A.; Abdelgader, A.G.; Turjoman, A.A.; Newell, K.; Hunsucker, S.W.; Shan, B.; Ma, B.; Gibson, D.S.; Duncan, M.W. Through the eye of an electrospray needle: Mass spectrometric identification of the major peptides and proteins in the milk of the one-humped camel (Camelus dromedarius). J. Mass Spectrom. 2013, 48, 779-794. [CrossRef]

37. Devendra, K.; Verma, A.K.; Chatli, M.K.; Singh, R.; Kumar, P.; Mehta, N.; Malav, O.P. Camel milk: Alternative milk for human consumption and its health benefits. Nutr. Food Sci. 2016, 46, 217-227.

38. Swelum, A.A.; El-Saadony, M.T.; Abdo, M.; Ombarak, R.A.; Hussein, E.O.S.; Suliman, G.; Alhimaidi, A.R.; Ammari, A.A.; Ba-Awadh, H.; Taha, A.E.; et al. Nutritional, antimicrobial and medicinal properties of Camel's milk: A review. Saudi J. Biol. Sci. 2021, 28, 3126-3136. [CrossRef]

39. El-Agamy, E.I.; Nawar, M.; Shamsia, S.M.; Awada, S.; Haenlein, G.H. Are camel milk proteins convenient to the nutrition of cow milk allergic children? Small Rumin. Res. 2009, 82, 1-6. [CrossRef]

40. Agrawal, R.P.; Jain, S.; Shah, S.; Chopra, A.; Agarwal, V. Effect of camel milk on glycemic control and insulin requirement in patients with type 1 diabetes: 2-years randomized controlled trial. Eur. J. Clin. Nutr. 2011, 65, 1048-1052. [CrossRef] [PubMed]

41. Zagorski, O.; Maman, A.; Yafee, A.; Meisles, A.; Van Creveld, C.; Yagil, R. Insulin in milk-A comparative study. Int. J. Anim. Sci. 1988, 13, 241-244.

42. Bath, D.P.; Kanga, U.; Kumar, N.; Agrawal, R.P.; Mourya, M.; Kalaivani, M.; Kaur, T.; Mehra, N.K. The Raikas-A unique combination of high prevalence of type 1 diabetes susceptibility genes and near zero incidence of the disease. Hum. Immunol. 2014, 75, 1252-1258.

43. Shabo, Y.; Yagil, R. Etiology of autism and camel milk as therapy. Int. J. Disab. Hum. Dev. 2005, 4, 67-70. [CrossRef]

44. Fantuz, F.; Salimei, E.; Papademas, P. Macro-and Micronutrients in Non-cow Milk and Products and Their Impact on Human Health. In Non-Bovine Milk and Milk Products; Tsakalidou, E., Papadimitriou, K., Eds.; Academic Press: London, UK, 2016; pp. 209-261.

45. Makinen-Kijunen, S.; Palosne, T. A sensitive enzyme-linked immunosorbent assay for determination of bovine beta-lactoglobulin in infant feeding formulas and human milk. Allergy 1992, 47, 347-352. [CrossRef]

46. Izadi, A.; Khedmat, L.; Yousef Mojtahedi, S.Y. Nutritional and therapeutic perspectives of camel milk and its protein hydrolysates: A review on versatile biofunctional properties. J. Funct. Foods 2016, 60, 103441. [CrossRef]

47. Abdel Gader, A.G.M.; Alhaider, A.A. The unique medicinal properties of camel products: A review of the scientific evidence. J. Taibah Univ. Med. Sci. 2016, 11, 98-103. [CrossRef]

48. Kamala, M.; Karoui, R. Monitoring of mild heat treatment of camel milk by front-face fluorescence spectroscopy. LWT Food Sci. Technol. 2017, 79, 586-593. [CrossRef]

49. Zhang, B.Y.; Xu, S.; Villalobos-Santeli, J.A.; Huang, J.Y. Fouling characterization of camel milk with comparison to bovine milk. J. Food Eng. 2020, 285, 110085. [CrossRef] 
50. Polidori, P.; Antonini, M.; Torres, D.; Beghelli, D.; Renieri, C. Tenderness evaluation and mineral levels of llama (Lama glama) and alpaca (Lama pacos) meat. Meat Sci. 2007, 77, 599-601. [CrossRef]

51. Riek, A.; Gerken, M. Changes in llama (Lama glama) milk composition during lactation. J. Dairy Sci. 2006, 89, 3484-3493. [CrossRef]

52. Martini, M.; Altomonte, I.; da Silva Sant'ana, A.M.; Del Plavignano, G.; Federica Salari, F. Gross, mineral and fatty acid composition of alpaca (Vicugna pacos) milk at 30 and 60 days of lactation. Small Rumin. Res. 2015, 132, 50-54. [CrossRef]

53. Wheeler, J.C. South American camelids-Past, present and future. J. Camelid Sci. 2012, 5, 1-24.

54. Park, Y.W.; Haenlein, G.F.W. Milk from Other Minor Species (Reindeer, Caribou, Musk Ox, Llama, Alpaca, Moose, Elk and Others). In Milk and Dairy Products in Human Nutrition: Production, Composition and Health, 1st ed.; Park, Y.W., Haenlein, G.F.W., Eds.; John Wiley \& Sons, Ltd.: New York, NY, USA, 2013; pp. 644-658.

55. Medina, M.; Van Nieuwenhove, G.A.; Pizarro, P.L.; Nieuwenhove, C.V. Comparison of the nutritional value and fatty acid composition of milk from four South American camelid species. Can. J. Zool. 2019, 97, 203-209. [CrossRef]

56. Ormachea, V.E.; Olarte, D.U.; Zanabria, H.V.; Melo, A.M.; Masias, G.Y. Milk composition in Huacaya alpaca (Vicugna pacos) and llama (Lama glama). Rev. Inv. Vet. Perú 2021, 32, e17800. [CrossRef]

57. Monti, G.; Viola, S.; Baro, C.; Cresi, F.; Tovo, P.A.; Moro, G.; Ferrero, M.P.; Conti, A.; Bertino, E. Tolerability of donkey's milk in 92 highly problematic cow's milk allergic children. J. Biol. Regul. Homeost. Agents 2012, 26 (Suppl. 3), 75-82.

58. Verduci, E.; D’Elios, S.; Cerrato, L.; Comberiati, P.; Calvani, M.; Palazzo, S.; Martelli, A.; Landi, M.; Trikamjee, T.; Peroni, D.G. Cow's milk substitutes for children: Nutritional aspects of milk from different mammalian species, special formula and plant-based beverages. Nutrients 2019, 11, 1739. [CrossRef] [PubMed]

59. Polidori, P.; Vincenzetti, S.; Pucciarelli, S.; Polzonetti, V. CLAs in Animal Source Foods: Healthy Benefits for Consumers. In Bioactive Molecules in Food, Reference Series in Phytochemistry; Mérillon, J.M., Ramawat, K.G., Eds.; Springer Nature: Cham, Switzerland, 2019; pp. 667-698.

60. Morin, D.E.; Rowan, L.L.; Hurley, W.L.; Braselton, W.E. Composition of Milk from Llamas in the United States. J. Dairy Sci. 1995, 78, 1713-1720. [CrossRef]

61. Polidori, P.; Vincenzetti, S. The Therapeutical, Nutritional and Cosmetic Properties of Donkey Milk; Cambridge Scholars Publishing: Cambridge, UK, 2019; pp. 45-68.

62. Altomonte, I.; Salari, F.; Licitra, R.; Martini, M. Donkey and human milk: Insights into their compositional similarities. Int. Dairy J. 2019, 89, 111-118. [CrossRef]

63. Guo, H.Y.; Ren, F.Z.; Zhang, X.Y.; Zhao, L.; Pang, K.; Chen, S.W.; Dong, M.L. Composition, Physiochemical Properties, Nitrogen Fraction Distribution, and Amino Acid Profile of Donkey Milk. J. Dairy Sci. 2007, 90, 1635-1643. [CrossRef]

64. Doreau, M.; Martin-Rosset, W. Dairy animals: Horse. In Encyclopedia of Dairy Sciences; Hubert, R., Ed.; Elsevier: Oxford, UK, 2002; pp. 630-637.

65. Raspa, F.; Cavallarin, L.; McLean, A.K.; Bergero, D.; Valle, E. A Review of the Appropriate Nutrition Welfare Criteria of Dairy Donkeys: Nutritional Requirements, Farm Management Requirements and Animal-Based Indicators. Animals $2019,9,315$. [CrossRef]

66. Roy, D.; Ye, A.; Moughan, P.J.; Singh, H. Composition, Structure, and Digestive Dynamics of Milk from Different Species-A Review. Front. Nutr. 2020, 7, 577759. [CrossRef]

67. Crowley, S.V.; Kelly, A.L.; Lucey, J.A.; O'Mahony, J.A. Potential applications of nonbovine mammalian milk in infant nutrition. In Handbook of Milk of Non-Bovine Mammals; Park, Y.W., Haenlein, G.F.W., Wendorff, W.L., Eds.; John Wiley \& Sons, Ltd.: Oxford, UK, 2017; pp. 625-654.

68. Ye, A.; Cui, J.; Carpenter, E.; Prosser, C.; Singh, H. Dynamic in vitro gastric digestion of infant formulae made with goat milk and cow milk: Influence of protein composition. Int. Dairy J. 2019, 97, 76-85. [CrossRef]

69. El-Hatmi, H.; Jrad, Z.; Salhi, I.; Aguibi, A.; Nadri, A.; Khorchani, T. Comparison of composition and whey protein fractions of human, camel, donkey, goat and cow milk. Mljekarstvo 2015, 65, 159-167. [CrossRef]

70. Martini, M.; Altomonte, I.; Licitra, R.; Salari, F. Short communication: Technological and seasonal variations of vitamin D and other nutritional components in donkey milk. J. Dairy Sci. 2018, 101, 8721-8725. [CrossRef] [PubMed]

71. Polidori, P.; Ariani, A.; Micozzi, D.; Vincenzetti, S. The effects of low voltage electrical stimulation on donkey meat. Meat Sci. 2016, 119, 160-164. [CrossRef]

72. Mäkinen, O.E.; Wanhalinna, V.; Zannini, E.; Arendt, E.K. Foods for Special Dietary Needs: Non-dairy Plant-based Milk Substitutes and Fermented Dairy-type Products. Crit. Rev. Food Sci. Nutr. 2016, 56, 339-349. [CrossRef]

73. Jeske, S.; Zannini, E.; Arendt, E.K. Evaluation of Physicochemical and Glycaemic Properties of Commercial Plant-Based Milk Substitutes. Plant Foods Hum. Nutr. 2017, 72, 26-33. [CrossRef]

74. Singhal, S.; Baker, R.D.; Baker, S.S. A Comparison of the Nutritional Value of Cow's Milk and Nondairy Beverages. J. Pediatr. Gastroenterol. Nutr. 2017, 64, 799-805. [CrossRef]

75. Tsakali, E.; Bosdra, K.; Giannopoulos, N.R.; Koulouris, S.; Houhoula, D.; Tsaknis, J.; Akkermans, S.; Van Impe, J.F.M. A Preliminary Study on the Development of Donkey Milk Based Fermented Product. Sci. Rev. Chem. Commun. 2017, 7, 113.

76. Tidona, F.; Charfi, I.; Povolo, M.; Pelizzola, V.; Carminati, D.; Contarini, G.; Giraffa, G. Fermented beverage emulsion based on donkey milk with sunflower oil. Int. J. Food Sci. Technol. 2015, 50, 2644-2652. [CrossRef]

77. Aspri, M.; Leni, G.; Galaverna, G.; Papademasa, P. Bioactive properties of fermented donkey milk, before and after in vitro simulated gastrointestinal digestion. Food Chem. 2018, 268, 476-484. [CrossRef] [PubMed] 
78. Tidona, F.; Criscione, A.; Guastella, A.M.; Bordonaro, S.; Marletta, D. Gross composition and nutritional properties of donkey milk produced in Sicily. J. Sci. Technol. 2011, 62, 217-221.

79. Coppola, R.; Salimei, E.; Succi, M.; Sorrentino, E.; Nanni, M.; Ranieri, P.; Belli Blanes, R.; Grazia, L. Behaviour of Lactobacillus rhamnosus strains in ass's milk. Ann. Microbiol. 2002, 52, 55-60.

80. Kopanos, G.K.; Puigjaner, L.; Georgiadis, M.C. Optimal production scheduling and lot-sizing in dairy plants: The yogurt production line. Ind. Eng. Chem. Res. 2010, 49, 701-718. [CrossRef]

81. Santini, G.; Bonazza, F.; Pucciarelli, S.; Polidori, P.; Ricciutelli, M.; Klimanova, Y.; Silvi, S.; Polzonetti, V.; Vincenzetti, S. Proteomic characterization of kefir milk by two-dimensional electrophoresis followed by mass spectrometry. J. Mass Spectrom. 2020 , e4635. [CrossRef]

82. Derdak, R.; Sakoui, S.; Pop, O.L.; Muresan, C.I.; Vodnar, D.C.; Addoum, B.; Vulturar, R.; Chis, A.; Suharoschi, R.; Soukri, A.; et al. Insights on Health and Food Applications of Equus asinus (Donkey) Milk Bioactive Proteins and Peptides-An Overview. Foods 2020, 9, 1302. [CrossRef] [PubMed]

83. Prado, M.R.; Blandón, L.M.; Vandenberghe, L.P.S.; Rodrigues, C.; Castro, G.R.; Thomaz-Soccol, V.; Soccol, C.R. Milk kefir: Composition, microbial cultures, biological activities, and related products. Front. Microbiol. 2015, 6, 1177. [CrossRef] [PubMed]

84. Perna, A.; Intaglietta, I.; Simonetti, A.; Gambacorta, E. Donkey milk for manufacture of novel functional fermented beverages. J. Food Sci. 2015, 80, S1352-S1359. [CrossRef]

85. Chiavari, C.; Coloretti, F.; Nanni, M.; Sorrentino, E.; Grazia, L. Use of donkey's milk for a fermented beverage with lactobacilli. Lait 2005, 85, 481-490. [CrossRef]

86. Barreto, Í.M.L.G.; Rangel, A.H.N.; Urbano, S.A.; Bezerra, J.S.; Oliveira, C.A.A. Equine milk and its potential use in the human diet. Food Sci. Technol. 2019, 39, 1-7. [CrossRef]

87. Vincenzetti, S.; Polidori, P.; Mariani, P.; Cammertoni, N.; Fantuz, F.; Vita, A. Donkey's milk protein fractions characterization. Food Chem. 2008, 106, 640-649. [CrossRef]

88. Carminati, D.; Tidona, F.; Fornasari, M.E.; Rossetti, L.; Meucci, A.; Giraffa, G. Biotyping of cultivable lactic acid bacteria isolated from donkey milk. Lett. Appl. Microbiol. 2014, 59, 299-305. [CrossRef]

89. Koroleva, N.S. Technology of kefir and kumys. Bull. Int. Dairy Fed. 1988, 227, 96-100.

90. Esener, O.B.B.; Balkan, B.M.; Armutak, E.I.; Uvez, A.; Yildiz, G.; Hafizoglu, M.; Yilmazer, N.; Gurel-Gurevin, E. Donkey milk kefir induces apoptosis and suppresses proliferation of Ehrlich ascites carcinoma by decreasing iNOS in mice. Biotech. Histochem. 2018, 93, 424-431. [CrossRef]

91. Mao, X.; Gu, J.; Sun, Y.; Xu, S.; Zhang, X.; Yang, H.; Ren, F. Antiproliferative and anti-tumour effect of active components in donkey milk on A549 human lung cancer cells. Int. Dairy J. 2009, 19, 703-708. [CrossRef]

92. Ayyash, M.; Al-Dhaheri, A.S.; Al Mahadin, S.; Kizhakkayil, J.; Abushelaibi, A. In vitro investigation of anticancer, antihypertensive, antidiabetic, and antioxidant activities of camel milk fermented with camel milk probiotic: A comparative study with fermented bovine milk. J. Dairy Sci. 2018, 101, 900-911. [CrossRef] [PubMed]

93. Nayak, C.M.; Ramachandra, C.T.; Kumar, G.M. A Comprehensive Review on Composition of Donkey Milk in Comparison to Human, Cow, Buffalo, Sheep, Goat, Camel and Horse Milk. Mysore J. Agric. Sci. 2020, 54, 42-50.

94. Ayyash, M.; Al-Nuaimi, A.K.; Al-Mahadin, S.; Liu, S.-Q. In vitro investigation of anticancer and ACE-inhibiting activity, $\alpha-$ amylase and $\alpha$-glucosidase inhibition, and antioxidant activity of camel milk fermented with camel milk probiotic: A comparative study with fermented bovine milk. Food Chem. 2018, 239, 588-597. [CrossRef] [PubMed]

95. Yahya, M.A.; Alhaj, O.A.; Al-Khalifah, A.S. Antihypertensive effect of fermented skim camel (Camelus dromedarius) milk on spontaneously hypertensive rats. Nutr. Hosp. 2017, 34, 416-421. [CrossRef] 